\title{
Polite Language in Boyolali Folklore
}

\author{
Ira Prihapsari ${ }^{1}, *$ Andayani $^{2}$, Sarwiji Suwandi ${ }^{3}$ \\ ${ }^{1,2,3}$ Department of Indonesian Language Education, Universitas Sebelas Maret, Surakarta, Indonesia \\ *Corresponding author. Email: ira_prihapsari@student.uns.ac.id
}

\begin{abstract}
This study aims to describe the politeness of the language contained in the folklore of Boyolali. This research is in the form of descriptive qualitative with the type of content analysis. The data in this study are in the form of language politeness in the folklore of Boyolali. Through this research, it can be seen that the Boyolali folklore contains a maxim of wisdom, a maxim of generosity, a maxim of appreciation, a maxim of consensus, and a maxim of sympathy. Maxims that reflect politeness in language can be used as a means of education for the younger generation.
\end{abstract}

Keywords: Folklore, Politeness in language, Maxims of politeness, Boyolali, Local wisdom

\section{INTRODUCTION}

Folklore is a tradition that is passed down from one generation to another from generation to generation. Folklore is an oral tradition that has been developed from generation to generation [1]. Folklore is an informal and traditional culture that is passed on by word of mouth [2].

Folklore contains the values of life that can be used to regulate the order of social life. The four functions of folklore are: (i) as a projection system, namely as a means of reflecting the dreams of a collective, (ii) as a means of ratifying cultural institutions and institutions, (iii) as an educational tool (pedagogical) device), and (iv) as a means of coercion and supervision so that the norms of society will always be obeyed by their collective members [3].

Folklore refers to behaviour and beliefs that contain values and meanings that are still relevant to life today [4]. In folklore, it can be found knowledge, values, attitudes, assumptions, feelings, beliefs that can be used as role models for someone to behave [5]. The collection of Boyolali folk tales contains the values of politeness which can be used to guide people's behaviour. Various folk tales can foster characters to love, respect, and protect nature in individuals as well as sharpen the cultural literacy of the community. As an educational tool, folklore can be used to educate politeness in language [6].
Politeness encourages people to be polite and can maintain one's stability in society [7]. Language politeness relates to the relationship between a person and another in language interactions. These politeness values can be observed from the dialogue spoken by the characters and from the descriptive depiction by the author. Leech also divides language politeness into maxims, namely the maxims of wisdom, generosity, respect, humility, sympathy, and compatibility.

Politeness is a product of conventions agreed upon by the community [8]. The politeness terrorism is grouped into two groups [9]. The first opinion is Brown and Levinson's politeness theory which divides politeness into two, namely, a negative face and a positive face. A negative face means the right to freedom of action and freedom from coercion, while a positive face is the need to be respected by others and to maintain a positive self-image.

Next is the Leech theory which divides politeness into several maxims, namely politeness, wisdom, agreement, sympathy, generosity, and agreement. In this study, the authors used the Leech language politeness theory.

\section{LITERATURE REVIEW}

\subsection{Folklore}

Folklore becomes part of the culture of society which is preserved consciously or unconsciously [10]. 
Anderson's opinion suggests that folklore has been passed down from generation to generation. Agree, Endraswara (2013: 2) states that folklore or folklore is part of a collective culture that is spread and passed down from generation to generation. Some expert opinions explain that folklore originated and developed from society.

Folklore as traditional knowledge of a culture [11]. Folklore is an informal and traditional culture in the form of culture - customs, stories, jokes, art — which are learned from one another and transmitted by word of mouth [12]. Folklore is an artistic process rather than a dusty artefact, since, in his words, it is something alive and dynamic. Folklore is a rich and meaningful source for the study of cognition and values [13]. Dundes' opinion explains that folklore is an artistic process from inheritance in the form of artefacts in the form of words that live dynamically in society and are full of values to be used as a guide for life.

Folklore is divided into three major groups, namely verbal folklore, material, and existing knowledge [14]. Verbal folklore includes any kind of knowledge that involves words, whether arranged to music, organized in the form of a chronological story, or simply the labelling of an activity or expressing beliefs with words or phrases. Some of the most familiar forms of verbal knowledge learned by folklorists are folk songs, myths, and folk tales.

It is different with material folklore, presenting a number of different forms, some of which are more or less permanent, such as architectural structures or functional tools, and some of which are temporary, such as food, body painting, or paper ornaments. Permanent or not, material culture is tangible - it can be touched, seen, eaten, or inhabited. In most cases these material objects are made by hand, but they can also be mass-produced items, such as holiday decorations, toys, or artefacts, that are used in an expressive way.

The third form is customary knowledge. Of the three genres, perhaps indigenous knowledge is the most difficult to characterize. Habits are repetitive and habitual actions; the usual way things are done. In line with the above opinion, William J. Thoms describes folklore as manners, habits, obedience, superstitions, ballads, and proverbs from the past [15]. Furthermore, William adds that folk tales are verbal, ranging from myths, legends, and folk tales to jokes, anecdotes, memorization, and even slang. The form of material folklore is in the form of making objects such as ceramic pots, origami, and carving pumpkins. More broadly, folklore can take the form of rituals, festivals, and beliefs.

The division of the types of folklore includes folk tales, nursery rhymes and some nonsense poems, myths, religious stories, epics, ballads, fairy tales, and legends [16].

\subsection{Polite Language}

Politeness of language emphasizes the relationship between language and usage in social phenomena [17]. Kesantuntan is also related to the interaction between communities [18]. Leech emphasized that politeness is able to build society in social relations. Politeness is also interpreted as facial work, which is a condition that shows one's self-respect towards other people in society [19].

\section{METHOD}

The form of this research is qualitative. Qualitative research begins with the assumptions and use of an interpretive / theoretical framework that informs the study of research problems that address the meaning an individual or group considers a social or human problem [20]. A qualitative approach allows a person to build a strong understanding of a topic by expressing meaning that comes from life in the form of activities, situations, circumstances, people, and an object [21]. Qualitative research is inductive in nature by developing concepts, insights, and understanding of patterns in data rather than collecting data to assess preconceived models, hypotheses, or theories [22].

In this study, the researcher served as a planner, implementer, data collector, analyser, data interpreter, and a reporter for the results of his research. The results of this study are not presented in the form of numbers, but rather a study and description of the object under study. The research strategy used is content analysis so that the data obtained is in the form of an analysis document.

\section{RESULT AND DISCUSSION}

Boyolali folklore contained in the book by Mardiyanto contains several maxim of language politeness. These include the maxims of wisdom, respect, humility/generosity, sympathy, compatibility. The maxims of wisdom are marked by showing a wise attitude. The maxim of generosity can be seen by showing an attitude of humility, generosity, respect, appreciation, offering to provide help. In addition, 
there is also a maxim of appreciation which contains speeches that do not ridicule each other, scorn each other, or belittle others, as well as respect for others. Next, the maxim of suitability is marked by affirming the question or statement presented by the interlocutor in the text. The forms of language politeness found in Boyolali folklore can be observed in the following table.

Table 1. A form of politeness in language

\begin{tabular}{|c|c|c|}
\hline $\begin{array}{l}\text { Maxim of Politeness } \\
\text { in Language }\end{array}$ & Quote & Form \\
\hline \multirow[t]{2}{*}{ Maxim of Wisdom } & $\begin{array}{l}\text { "Servant does not ask for money," said the beggar, "I only ask for the } \\
\text { sound of the drum sound in the Semarang mosque. And Sir, don't just } \\
\text { think about wealth because life is temporary. The property will not be } \\
\text { taken to death. In heaven we will not be short of things. beautiful things, } \\
\text { whatever we want, there must be. (Page 11) }\end{array}$ & $\begin{array}{l}\text { It is wise to live a life: the } \\
\text { assumption that the world is } \\
\text { only temporary so that it } \\
\text { focuses more on worship }\end{array}$ \\
\hline & $\begin{array}{l}\text { "The two robbers admitted their mistakes and apologized to Ki Ageng } \\
\text { Pandanarang. Furthermore, they served Ki Ageng Pandanarang. "Page } \\
15\end{array}$ & Forgive others. \\
\hline \multirow[t]{3}{*}{ Maxim of Generosity } & $\begin{array}{l}\text { It so happened that at that time Ki Ageng Pandanarang was counting } \\
\text { money in the palace hall. Ki Ageng Pandanarang gave money to the } \\
\text { beggar, but the beggar refused. }\end{array}$ & Give to the needy. \\
\hline & $\begin{array}{l}\text { "Forgive me Kyai because I have insulted and underestimated Kyai," said } \\
\text { Ki Ageng Pandanarang softly "Page } 12\end{array}$ & Apologize to admit mistakes. \\
\hline & $\begin{array}{l}\text { "To overcome this drought I have to immediately find a source of water," } \\
\text { muttered Raden Bagus Kencana sadly. Page } 60\end{array}$ & Willing to sacrifice for others. \\
\hline \multirow[t]{4}{*}{ Maxim of Appreciation } & $\begin{array}{l}\text { "After the meal was over, Ki Ageng Pandanarang invited his guests to tour } \\
\text { the palace. The guests praised and admired the beauty of the Semarang } \\
\text { Kadipaten palace. " Page } 11\end{array}$ & Entertain guests well. \\
\hline & $\begin{array}{l}\text { Ki Lindhu worshiped, "Servant named Lindhu. My residence is in } \\
\text { Karanggeneng Village, on the north side of the road." Page } 25\end{array}$ & $\begin{array}{l}\text { Respecting others in higher } \\
\text { positions by worshiping. }\end{array}$ \\
\hline & $\begin{array}{l}\text { "Ki Lindhu thanked him and excused himself and wanted to bring the } \\
\text { gamelan home. Patih Bandamyamun immediately returned to the Kraton } \\
\text { Leses palace. "Page } 26\end{array}$ & Thank you for the help given. \\
\hline & $\begin{array}{l}\text { In front of the Prophet Soleman, Dewi Sri said while worshiping, "Sir, I ask } \\
\text { for justice because the rice plants in the Land of Java were destroyed by } \\
\text { Jayawirog and its people." Page } 50\end{array}$ & $\begin{array}{l}\text { Respecting others in higher } \\
\text { positions by worshiping. }\end{array}$ \\
\hline \multirow[t]{3}{*}{ Max Match } & "Sunan Kalijaga is very happy to have this noble task" (page 10) & Approve requests. \\
\hline & $\begin{array}{l}\text { "I will carry out all the Kyai's requests," said Ki Ageng Pandanarang } \\
\text { without hesitation. Page } 13\end{array}$ & Approve requests. \\
\hline & $\begin{array}{l}\text { "King Gebluk Kusuma could not bear to refuse Ki Lindu's request," I will } \\
\text { lend Kanjeng Kyai Leses gamelan. "Page } 25\end{array}$ & Approve requests. \\
\hline
\end{tabular}

\subsection{Maxim of Wisdom}

The maxim of wisdom is contained in the story entitled "The Origin of the Name of Boyolali City" which appears in the following quote.

"Servant does not ask for money," said the beggar, "I only ask for the sound of the drum sound in the
Semarang mosque. And Sir, don't just think about wealth because life is temporary. The property will not be taken to death. In heaven we will not be short of things. beautiful things, whatever we want, there must be. (Page 11) 
The quotation explains that a person's wisdom appears to be a principle held firmly by society. This is shown by Sunan Kalijaga's wise attitude in thinking about life, namely the assumption that the world is only temporary so that desire tends to be more focused on future orientation, namely the focus of worship.

Wisdom is also shown by $\mathrm{Ki}$ Pandanarang's attitude, which is to forgive the mistakes of others and to give other people the opportunity to return the favour, as shown in the quote below.

"The two robbers admitted their mistakes and apologized to Ki Ageng Pandanarang. Furthermore, they served Ki Ageng Pandanarang. " (Page 15)

\subsection{Maxim of Generosity}

The maxim of generosity is found in the folklore entitled "The Origin of the Name of Boyolali City" which is indicated by the following quote.

It so happened that at that time $\mathrm{Ki}$ Ageng Pandanarang was counting money in the palace hall. Ki Ageng Pandanarang gave money to the beggar, but the beggar refused.

Generosity was shown by the attitude of Ki Ageng Pandanarang who gave money to beggars who came to the palace pendapa. Generosity is also shown in the following quote.

"Forgive me Kyai because I have insulted and underestimated Kyai," said Ki Ageng Pandanarang softly " (Page 12)

The quote shows that someone who is generous will be able to appreciate others, even though he has been guilty, he is not ashamed to admit mistakes that have been done and dare to apologize to others. Generosity can also be manifested in an attitude of compassion, which is the desire to help others or make sacrifices for others. This can be observed in the following quotation.

"To overcome this drought I have to immediately find a source of water," muttered Raden Bagus Kencana sadly. Page 60

The above quote explains that Raden Bagus Kencana has a generous attitude with the intention of helping to find water sources for the people in Kademangan Catursari.

\subsection{Maxim of Appreciation}

The form of respect for others can be seen in the quotation below.
"After the meal was over, Ki Ageng Pandanarang invited his guests to tour the palace. The guests praised and admired the beauty of the Semarang Kadipaten palace. " (Page 11)

The above quote explains that $\mathrm{Ki}$ Ageng Pandanarang has practiced the behavior of giving respect to others, namely by entertaining his guests by taking them around the palace. Entertaining guests is a form of appreciation to others. Another form of appreciation can also be seen in the following quote.

Ki Lindhu worshiped, "Servant named Lindhu. My residence is in Karanggeneng Village, on the north side of the road." (Page 25)

In the above quotation it is known that when meeting someone who is considered older, one must introduce himself and pay respect. The tribute made by Ki Lindhu to King Geblug Kusuma. Other forms of appreciation also appear in the quotation below.

"Ki Lindhu thanked him and excused himself and wanted to bring the gamelan home. Patih Bandamyamun immediately returned to the Kraton Leses palace. " (Page 26)

Saying thanks to others who have helped is a form of appreciation to others. Apart from words, appreciation can also be done in the form of behavior or activities, as shown in the following quote.

In front of the Prophet Soleman, Dewi Sri said while worshiping, "Sir, I ask for justice because the rice plants in the Land of Java were destroyed by Jayawirog and its people." (Page 50)

The above quote illustrates that respect can be done by means of worship. This illustrates that the interlocutor has a more noble position than himself.

\subsection{Max Match}

Maxim of suitability can be manifested in words or behaviours that tend to agree or affirm a condition. This can be seen in the quotation below.

"Sunan Kalijaga is very happy to have this noble task" (page 10)

Compatibility can be seen in the attitude of Sunan Kalijaga who is happy to get a job. That is, Sunan Kalijaga agreed with the assigned task. Another form is also shown by Ki Ageng Pandanarang who stated the following suit.

"I will carry out all the Kyai's requests," said Ki Ageng Pandanarang without hesitation. (Page 13) 
The above quote explains that $\mathrm{Ki}$ Ageng Pandanarang approved all requests submitted by Kyai, he clearly agreed or matched the requests submitted.

"King Gebluk Kusuma could not bear to refuse $\mathrm{Ki}$ Lindu's request," I will lend Kanjeng Kyai Leses gamelan. " Page 25

The above quote explains that Prabu Gebluk Kusuma agreed with $\mathrm{Ki}$ Lindu's request.

Based on the findings above, it can be concluded that the Boyolali folklore contains various principles of politeness which can be used as a medium for teaching language politeness. In addition to respecting the existing culture in the surrounding area, the community is also able to recognize the manners that must be emulated when talking to other people.

\section{CONCLUSION}

The folklore of Boyolali contains various principles of politeness which can be used as a medium for teaching politeness, including wisdom, generosity, respect, and compatibility.

\section{AUTHORS' CONTRIBUTIONS}

The contributions of each author are as follows conceived and designed the analysis, collect the data, contributed data or analysis tools, performed the analysis, and wrote the paper.

\section{ACKNOWLEDGMENTS}

Thanks to the University Centre of Excellence Javanologi for Javanese Traditions Universitas Sebelas Maret for publication. We also thank the LPDP for funding this research.

\section{REFERENCES}

[1] Vansina, J. (1985). Oral tradition as history. United States of America: The University of Wisconsin Press.

[2] McNeill, LS (2013). Folklore Rules. United States of America: University Press of Colorado.

[3] Bascom, WR (1965). Four Function of Folklore. Englewood Cliff: NJ. Prentice Hall, Inc.

[4] Foster, MD (2015). The Book of Yokai: Mysterious Creatures of Japanese Folklore. United States of America: University of California Press.
[5] Sims, MC \& Stephens, M. (2011). Living Folklore: An Introduction to The Study of People and Their Traditions: Second Edition, Revised. United States of America: Utah State University Press.

[6] Sukmawan, S., \& Setyowati, L. (2017). Environmental Messages as Found in Indonesian Folklore and Its Relation to Foreign Language Classroom. Arab World English Journal, 8 (1), 298-308.

https://doi.org/10.24093/awej/vol8no1.21

[7] Leech, G. (2014). The Pragmatics of Politeness. Oxford University Press.

[8] Ward, G. \& Horn, LR (2006). The Handbook of Pragmatics. Austria: Blackwell Publishing.

[9] Black, Elizabeth Black. (2006). Pragmatic Stylistics. Great Britain: Edinburgh University Press.

[10] Anderson, G. (2006). Greek and Roman Folklore: A Handbook. United States of America: Greenwood Publishing Group, Inc.

[11] Untiedt, KL (2006). Folklore: In All of Us, In All We Do. United States of America: University of North Texas Press.

[12] McNeill, LS (2013). Folklore Rules. United States of America: University Press of Colorado.

[13] Dundes, A. (2007). The Meaning of Folklore: The Analytical Essays of Alan Dundes. Logan: Utag State University Press.

[14] Sims, MC \& Stephens, M. (2011). Living Folklore: An Introduction to The Study of People and Their Traditions: Second Edition, Revised. United States of America: Utah State University Press.

[15] Foster, MD (2015). The Book of Yokai: Mysterious Creatures of Japanese Folklore. United States of America: University of California Press.

[16] Sherman, J. (2008). Story telling. New York: Sharpe Reference.

[17] Leech, G. (2014). The Pragmatics of Politeness. Oxford University Press.

[18] Leech, G. (1983). Principle of Pragmatics: Eight Impressions. New York: Longman Group UK Ltd. 
[19] Goffman, E., 1967. The nature of deference and demeanor. In: Goffman, E. (Ed.), Relations in Public: Microstudies of the Public Order. Harper and Row, New York.

[20] Creswell, JW (2013). Qualitative Inquiry \& Research Design. United Kingdom: SAGE Publications, Inc.

[21] Leavy, P. (2017). Research Design. New York: The Guilford Press.

[22] Devault, ML, Bogdan, R., Taylor, SJ (2016). Introduction to Qualitative Research Methods. United States of America: John Wiley \& Sons. 